\title{
PENGEMBANGAN MODEL BUKU AJAR MEMBACA \\ BERDASARKAN PENDEKATAN PROSES BAGI SISWA SMP
}

\author{
Kastam Syamsi, Esti Swatika Sari, dan Setyawan Pujiono \\ FBS Universitas Negeri Yogyakarta \\ email: kastam@uny.ac.id
}

\begin{abstract}
Abstrak: Penelitian pengembangan ini bertujuan untuk menghasilkan model buku ajar membaca berdasarkan pendekatan proses bagi siswa SMP. Ada tiga tahap dalam penelitian ini, yaitu (1) pendefinisian; (2) perencanaan dan pengembangan; dan (3) penyebarluasan. Data penelitian dianalisis dengan teknik analisis domain dengan prinsip kritis dan reflektif. Temuan penelitian menunjukkan bahwa model buku ajar membaca telah dikembangkan berdasarkan pendekatan proses. Buku tersebut terdiri atas tiga bagian, yaitu (1) pendahuluan, (2) bagian isi, dan (3) bagian tambahan. Setiap unit terdiri atas judul unit pembelajaran, kompetensi dasar, pramembaca, membaca, merespon, menggali teks, dan memperluas pemahaman.
\end{abstract}

Kata Kunci: buku ajar membaca, pendekatan proses

\section{DEVELOPING A PROCESS-APPROACH-BASED READING TEXTBOOK MODEL FOR JUNIOR HIGH SCHOOL STUDENTS}

\begin{abstract}
This development research was aimed to produce a process-approach-based reading textbook model for Junior High School students. There were three stages in this research, i.e. (1) definition; (2) design and development; and (3) dissemination. The data were analyzed using the domain analysis technique with critical and reflective principles. The findings showed that the reading textbook model had been developed based on the process approach. This text book consisted of three parts, i.e. (1) introduction, (2) core materials, and (3) additional part. Each unit consisted of the title, competence, pre-reading, whilst-reading, responding, exploring the text, and extending comprehension.
\end{abstract}

Keywords: reading text book, process approach

\section{PENDAHULUAN}

Membaca merupakan keterampilan yang paling utama yang harus dipelajari oleh peserta didik. Hal ini dapat dipahami sebab keberhasilan peserta didik dalam belajar ditentukan oleh kemampuannya dalam membaca. Melalui membaca pula seseorang dapat berkomunikasi dengan tulisan tanpa harus berhadapan langsung dengan penulisnya.

Meskipun dipercaya bahwa kemampuan membaca dikembangkan melalui latihan, para ahli bersepakat bahwa membaca yang efektif dapat pula diajarkan kepada peserta didik. Namun demikian, kenyataan menunjukkan bahwa kemampuan membaca anak-anak Indonesia masih memrihatinkan. Dalam penelitian yang dilakukan Progress in International Reading
Literacy Study (PIRLS) 2011 (Mullis, Nartin, Foy, \& Drucker, 2012) disebutkan bahwa kemampuan membaca anak-anak sekolah dasar di Indonesia menduduki posisi ke-42 di antara 45 negara yang diteliti dengan rerata skor 428. Ini berarti kemampuan membaca anak-anak Indonesia masib tergolong rendah.

Di sisi lain, belum tersedia buku ajar membaca (sebagian atau merupakan bagian dari buku pelajaran Bahasa Indonesia) yang dikembangkan berdasarkan pendekatan atau metode pembelajaran tertentu. Padahal, seperti dinyatakan Sumardi (2000), buku ajar semestinya disusun berdasarkan pendekatan pembelajaran tertentu sehingga memiliki landasan dan arah yang jelas. Buku ajar memiliki kedudukan dan fungsi 
yang penting dalam kegiatan pembelajaran di sekolah (Sumardi, 2000; Muslich, 2010).

Salah satu upaya untuk meningkatkan kualitas pembelajaran membaca adalah dengan melakukan inovasi model pembelajaran melalui penerapan pendekatan proses (Tomkins \& Hoskisson, 1995; Tomkins, 2010). Berdasarkan pertimbangan itulah, penelitian ini ingin mengembangkan model buku ajar membaca berdasarkan pendekatan proses bagi peserta didik SMP.

Penelitian ini dirancang untuk menghasilkan model bukuajar membaca berdasarkan pendekatan proses bagi siswa SMP. Oleh karena itu, manfaat penelitian ini dapat dilihat dari aspek teoretis dan praktis. Secara teoretis, diharapkan hasil penelitian ini dapat menemukan dan memperkaya khasanah model pembelajaran membaca yang sudah ada. Sementara itu, secara praktis diharapkan hasil penelitian ini bermanfaat bagi guru, peserta didik, dan penulis buku ajar. Bagi guru, diharapkan hasil penelitian ini dapat digunakan sebagai alternatif model pelaksanaan kegiatan pembelajaran membaca dalam mata pelajaran Bahasa Indonesia di sekolah yang tepat, efektif, dan efisian. Bagi peserta didik, diharapkan hasil penelitian ini dapat digunakan sebagai panduan belajar membaca yang tepat, efektif, dan efisien. Bagi penulis buku ajar, hasil penelitian ini diharapkan memberikan sumbangan informasi bagi penulisan buku pelajaran khususnya dalam pengembangan materi pembelajaran membaca.

Buku teks adalah buku yang dijadikan pegangan peserta didik pada jenjang pendidikan tertentu sebagai media pembelajaran berkaitan dengan bidang studi tetentu (Depdiknas, 2006a). Buku ajar, disebut juga buku teks pelajaran, dengan demikian merupakan buku yang menjadi acuan kegiatan belajar peserta didik. Oleh karena itu, menurut Muslich (2010), buku ajar memiliki kedudukan dan fungsi yang penting dalam kegiatan pembelajaran.

Sebagai salah satu bentuk materi pelajaran itu, buku pelajaran umumnya merupakan sumber utama kegiatan pembelajaran bahasa. Dalam pembelajaran bahasa, buku pelajaran merupakan suatu sarana untuk pembelajaran prosedur, konsep, strategi, dan keterampilan berbahasa (Tomkins \& Hoskisson, 1995:42). Di dalam buku pelajaran tersebut disajikan konsep, contoh, dan kegiatan latihan berbahasa.

Buku pelajaran berisi unit-unit materi pembelajaran yang harus diikuti oleh peserta didik melalui serangkaian kegiatan dan pelatihan seperti membaca teks, menganalisis teks, mendiskusikan isi teks, merefleksi, dan lainlain. Ada guru yang mengambil materi ajar dari buku pelajaran, tetapi ada juga yang tidak menggunakannya sama sekali. Selain itu, ada juga guru yang menggunakan buku pelajaran secara selektif, dalam arti ia hanya memilih materi dari buku pelajaran yang diperlukan sesuai dengan kebutuhan dan kurikulum yang berlaku (Ur, 2009:183).

Menurut Tomlinson (1998:7-22), dalam pengembangan materi pembelajaran bahasa hendaknya diperhatikan beberapa prinsip dasar. Prinsip-prinsip dasar pengembangan materi pembelajaran bahasa itu adalah (1) materi pembelajaran semestinya memiliki pengaruh yang kuat kepada peserta didik; (2) materi pembelajaran harus membantu peserta didik merasa mudah belajar; (3) materi pembelajaran harus membantu peserta didik untuk berkembang dengan penuh percaya diri; (4) materi pembelajaran harus menyediakan dan memfasilitasi peserta didik menjadi pembelajar yang mandiri; (5) materi pembelajaran semestinya tersedia sesuai dengan fokus pembelajaran yang diajarkan; (6) materi pembelajaran harus memberi kesempatan pada peserta didik untuk menggunakan bahasa yang otentik; (7) perhatian peserta didik harus diberikan melalui penggunaan gaya bahasa sebagai input, (8) materi pembelajaran harus memberi kesempatan peserta didik untuk mempelajari bahasa target untuk tujuan komunikasi, (9) materi pembelajaran harus memperhitungkan efek positif dalam pembelajaran, (10) materi pembelajaran harus memperhitungkan perbedaan gaya belajar peserta didik, (11) materi pembelajaran harus memperhitungkan perbedaan sikap peserta didik, (12) materi pembelajaran harus memungkinkan adanya periode hening pada awal kegiatan pembelajaran, (13) materi pembelajaran hendaknya dapat memaksimalkan potensi belajar peserta didik, (14) 
materi pembelajaran seharusnya tidak terlalu mengontrol latihan peserta didik, dan (15) materi pembelajaran harus menyediakan kesempatan untuk pemberian umpan balik.

Ur (2009:193) memberikan petunjuk jika guru ingin mengembangkan dan menulis bahan ajar sendiri. Petunjuk itu adalah (1) materi hendaknya ditulis dengan rapi dan bersih; (2) materi dimulai dengan instruksi yang singkat dan jelas, serta disertai contoh; (3) agar materi lebih jelas dan menarik, harus menggunakan tata letak, ilustrasi, dan gambar yang seimbang dan bervariasi; (4) tugas-tugas disampaikan dengan cukup jelas untuk dapat dipahami sendiri oleh peserta didik. Hyland (2007:92) menambahkan bahwa dalam mengembangkan buku ajar pembelajaran bahasa harus memperhatikan keotentikan contoh teks yang disajikan.

Dalam penyusunan buku pelajaran terdapat standar mutu yang harus diperhatikan (Depdiknas, 2006a; Depdikas, 2006b). Standar mutu buku pelajaran mencakup aspek (1) isi atau materi pelajaran, (2) penyajian materi, (3) bahasa dan keterbacaan, dan (4) format buku atau kegrafikaan. Aspek isi atau materi pelajaran meliputi kriteria (1) kesesuaian materi dengan kurikulum; (2) kesesuaian materi dengan tujuan pendidikan; (3) kebenaran materi dilihat dari segi ilmu; dan (4) kesesuaian materi dengan perkembangan kognitif peserta didik. Aspek penyajian materi meliputi kriteria adanya (1) tujuan pelajaran; 2) penahapan pembelajaran; (3) penyajian yang menarik minat dan perhatian peserta didik; (4) kemudahan bahan untuk dipahami; (5) keaktifan peserta didik; (6) hubungan antarbahan, (7) latihan; dan (8) soal.

Aspek bahasa dan keterbacaan meliputi kriteria (1) penggunaan bahasa Indonesia yang baik dan benar; (2) penggunaan bahasa yang dapat meningkatkan daya nalar dan daya cipta peserta didik; (3) penggunaan struktur kalimat yang sesuai dengan tingkat penguasaan bahasa peserta didik dan tingkat perkembangan peserta didik; (5) penggunaan paragraf; dan (5) materi dan ilustrasi. Aspek kegrafikaan meliputi kriteria (1) ukuran buku; (2) tata letak; tipografi, dan ilustrasi sampul; dan (3) tata letak, tipografi, dan ilustrasi isi.
Model buku ajar membaca yang dikembangkan relatif berbeda dengan model buku ajar yang biasa digunakan guru atau telah dikembangkan oleh peneliti lain. Guru pada umumnya mengajar membaca berbasis teks dan atau buku teks pelajaran atau bahkan LKS (Lembar Kerja Siswa) yang sudah tersedia. Sejauh pengamatan, belum pernah dilakukan pengembangan model buku ajar membaca berdasarkan pendekatan proses bagi siswa SMP.

Pembelajaran membaca dengan pendekatan proses meliputi langkah-langkah: persiapan untuk membaca, membaca, merespon, mengeksplorasi teks, dan memperluas interpretasi. Proses membaca tidak dimulai dengan membuka buku dan langsung membaca (Tomkins \& Hoskisson, 1995; Tomkins, 2010), tetapi melalui persiapan. Adapun langkah-langkah yang dilakukan pada tahap persiapan adalah (1) memilih teks; (2) menghubungkan teks dengan pengalaman pribadi dan pengalaman membaca sebelumnya; (3) memprediksi isi teks; dan (4) mengadakan tinjauan pendahuluan terhadap teks. Tujuan utama tahap ini adalah untuk mengaitkan antara pengetahuan sebelumnya dengan teks yang akan dibaca.

Pada tahap kedua, yakni membaca, peserta didik membaca teks secara keseluruhan. Ada lima macam model membaca yang dapat dilakukan (Tomkins \& Hoskisson, 1995; Tomkins, 2010), yakni (1) membaca nyaring (reading aloud); (2) membaca bersama (shared reading); (3) membaca berpasangan (buddy reading); (4) membaca terbimbing (guided reading); dan (5) membaca bebas (independent reading). Kelima macam model membaca ini dapat diterapkan sesuai dengan jenis dan tujuan pembelajaran membaca di sekolah.

Pada tahap ketiga, merespon, peserta didikmemberi tanggapan terhadap kegiatan membaca mereka dan terus berusaha memahami isi. Ada dua langkah yang dapat dilakukan peserta didik untuk tahap ini (Tomkins \& Hoskisson, 1995; Tomkins, 2010), yakni (1) memberi tanggapan dalam bentuk tertulis pada format hasil membaca; dan (2) berpartisipasi dalam diskusi klasikal. Kedua langkah ini dapat di- 
terapkan sesuai dengan situasi dan kebutuhan di kelas.

Setelah memberi respon, para peserta didik kembali memperhatikan teks untuk menggali isinya lebih dalam lagi. Pada tahap ini peserta didik melakukan langkah-langkah: (1) membaca ulang teks; (2) menemukan gaya bahasa khusus penulis (the author's craft); (3) mempelajari kosakata baru; (4) mengidentifikasi ide bacaan; dan (5) berpartisipasi dalam pengajaran singkat yang dilakukan guru (Tomkins \& Hoskisson, 1995; Tomkins, 2010). Kegiatan menggali teks ini lebih dimaksudkan untuk memahami isi bacaan secara lebih mendetail.

Pada tahap terakhir dalam proses membaca, yakni memperluas interpretasi, dapat dilakukan kegiatan-kegiatan: (1) mereproduksi teks dengan bahasa sendiri; (2) bermain peran sesuai dengan isi teks; (3) mempresentasikan isi teks dengan program Powerpoint (Tomkins, 2010). Ketiga kegiatan itu dapat dilakukan dengan melibatkan keterampilan berbahasa yang lain, seperti berbicara dan menulis. Kegiatan seperti bermain peran, berwawancara atau melakukan tugas atau proyek khusus juga dapat dilakukan untuk memperluah pemahaman siswa.

\section{METODE}

Model desain penelitian pengembangan ini adalah Recursive Reflective Design and Development (R2D2) yang dikembangkan oleh Willis (1995) berdasarkan pandangan konstruktivisme. Desain ini dipilih dengan pertimbangan bahwa desain ini bersifat reflektif, rekursif, kolaboratif, dan berkembang sehingga memberi kesempatan peneliti dan pihak-pihak yang terkait untuk mengembangkan produk pembelajaran, yakni buku ajar, yang sesuai dengan kebutuhan secara terus-menerus sampai ditemukan produk yang dianggap paling tepat, efektif, dan efisien.

Prosedur penelitian pengembangan ini terdiri dari tiga tahap, yakni (1) pendefinisian, (2) perencanaan dan pengembangan, dan (3) penyebarluasan. Aktivitas pendefinisian difokuskan pada (1) menciptakan kerja sama tim,
(2) solusi problem progresif, dan (3) pemahaman masalah secara kontekstual. Aktivitas perencanaan dan pengembangan difokuskan pada (1) mempelajari konteks pembelajaran, (2) memilih format dan media, (3) menentukan strategi evaluasi, dan (4) mendesain produk dan pengembangannya. Aktivitas penyebarluasan difokuskan pada (1) evaluasi otentik, dan (1) penyusunan paket akhir produk sesuai dengan konteks.

Untuk mengetahui kelayakan produk yang dikembangkan, telah dilakukan uji produk. Uji produk yang dilakukan terdiri dari uji ahli, uji praktisi (guru), dan uji pengguna (peserta didik). Berdasarkan hasil uji produk tersebut dilakukan revisi terhadap model buku ajar yang dikembangkan.

Subjek uji produk penelitian ini meliputi tiga kelompok. Pertama, kelompok ahli yang terdiri dari tiga orang ahli metodologi pembelajaran bahasa Indonesia. Kedua, kelompok guru yang terdiri dari tiga orang guru mata pelajaran Bahasa Indonesia di SMP Negeri 1 Kalasan Kabupaten Sleman dan dua orang guru pengurus MGMP Bahasa Indonesia SMP Kabupaten Sleman, Provinsi Daerah Istimewa Yogyakarta. Ketiga, kelompok peserta didik yang terdiri dari sepuluh orang peserta didik SMP Negeri 1 Kalasan Kabupaten Sleman.

Pengumpulan data dilakukandengan pemberian angket dan lembar saran kepada subjek uji produk. Angket untuk ahli pembelajaran Bahasa Indonesia dan guru berkaitan dengan ketepatan konsep materi pelajaran, penyajian materi, bahasa, dan kegrafikaan yang terdiri dari 28 butir pernyataan. Angket untuk peserta didik berkaitan dengan kepraktisan penggunaan buku ajar yang terdiri dari 12 pertanyaan. Pilihan jawaban untuk angket berupa skala 1-4 yang bersifat gradasi (skor 1= tidak layak, 2 = agak layak, 3 = layak; 4= sangat layak).

Data penelitian ini adalah data validasi hasil pengembangan buku ajar yang diperoleh ketika uji produk. Data angka dari angket dianalisis dengan teknik persentase, sedang data verbal yang berupa kritik, saran, dan komentar yang ditulis pada berkas model buku ajar atau lembar instrumen penilaian dianalisis dengan 
teknik analisis domain dengan prinsip kritis dan reflektif. Hasil penilaian dalam uji produk melalui angket peniliaian menunjukkan kualitas draf model buku ajar yang dikembangkan. Masukan yang berupa kritik, saran, dan komentar menunjukkan harapan subjek uji produk agar buku ajar disusun lebih baik. Data tersebut digunakan untuk merevisi dan menyempurnakan model buku ajar.

\section{HASIL DAN PEMBAHASAN}

\section{Model Buku Ajar Membaca Berdasarkan Pendekatan Proses}

Produk pengembangan ini berupa model Buku Ajar Membaca Berdasarkan Pendekatan Proses bagi Peserta didik SMP. Model buku ajar ini terdiri dari tiga bagian, yakni (1) bagian pendahuluan, (2) bagian isi, dan (3) bagian tambahan. Bagian pendahuluan terdiri dari sampul, kata pengantar dan daftar isi. Bagian isi terdiri dari sepuluh unit pelajaran membaca, yang mencakup (1) membaca memindai; (2) membaca cepat; (3) membaca cerita anak; (4) membaca dan mengomentari buku cerita; (5) membaca indah puisi; (6) membaca cerita anak dan menemukan realitas dalam kehidupan; (7) membaca intensif buku biografi; (8) membaca intensif untuk menemukan gagasan utama; (9) membaca tabel/ diagram; dan (10) membaca teks perangkat upacara. Bagian tambahan berupa daftar pustaka.

\section{Hasil Uji Ahli dan Revisi Model Buku Ajar}

Data hasil uji ahli menunjukkan bahwa model buku ajar yang dikembangkan termasuk kategori layak (rerata skor 3.59). Saran atau komentar ahli terhadap model buku ajar itu adalah: (1) perbaikan ketepatan penggunaan ejaan, (2) perbaikan penggunaan istilah dan kosakata; misalnya kegiatan diganti menjadi langkah; dan (3) perlu penambahan pengertian tentang konsep jenis membaca pada tahap pramembaca. Berdasarkan saran tersebut, telah dilakukan revisi model buku ajar. Perbaikan itu meliputi (1) perbaikan penggunaan ejaan; (2) perbaikan penggunaan istilah atau kosa kata yang lebih tepat; dan (3) penambahan pengertian jenis membaca pada tahap pramembaca setiap unit pelajaran.

\section{Hasil Uji Praktisi (Guru) dan Revisi Model Buku Ajar}

Data hasil uji praktisi (guru) menunjukkan bahwa model buku ajar yang dikembangkan termasuk kategori sangat layak (rerata skor 3,82). Saran atau komentar dari praktisi (guru) adalah (1) perbaikan ketepatan penggunaan ejaan; (2) perbaikan penggunaan istilah dan kosakata; dan (3) perbaikan penulisan judul teks sesuai dengan teks yang dirujuk, misalnya pada halaman 21 terdapat teks cerita anak berjudul Istana Bunga, semestinya pada halaman 20 pada bagian berdiskusi juga disebut cerita anak yang berjudul Istana Bunga bukan Pangeran Remeh. Berdasarkan saran atau komentar tersebut, telah dilakukan revisi model buku ajar. Adapaun perbaikan yang dilakukan mencakup (1) perbaikan ketepatan penggunaan ejaan; (2) perbaikan penggunaan istilah dan kosa kata; dan (3) perbaikan penulisan judul teks sesuai dengan teks yang dirujuk.

\section{Hasil Uji Pengguna (Peserta Didik) dan Revisi Model Buku Ajar}

Data hasil uji pengguna (peserta didik) menunjukkan bahwa model buku ajar yang dikembangkan termasuk kategori sangat layak. Saran atau komentar dari pengguna (peserta didik) adalah (1) penggantian kata-kata yang mengandung makna yang sulit; (2) perbaikan tata letak dan gambar supaya lebih menarik; dan (3) kejelasan pemberian tugas, apakah dilakukan secara individu atau kelompok. Berdasarkan saran atau komentar tersebut, telah dilakukan revisi model buku ajar. Adapun perbaikan yang dilakukan mencakup (1) ketepatan penggunaan kata; (2) tata letak dan gambar; dan (3) ketegasan pemberian tugas secara individu atau kelompok.

\section{Pembahasan}

Hasil uji ahli, uji praktisi (guru), dan uji pengguna (peserta didik) menunjukkan bahwa model buku ajar yang dikembangkan masuk ke dalam kategori layak atau baik. Rata-rata skor keseluruhan yang diperoleh dari penilaian ahli adalah 3.59. Rata-rata skor keseluruhan yang diperoleh dari penialaian praktisi (guru) adalah 
3.82. Sementara itu, rata-rata skor keseluruhan penialaian dari pengguna (peserta didik) adalah 3.85 .

Hasil penilaian yang diberikan oleh pakar menunjukkan bahwa model buku ajar yang dikembangkan dipandang dari segi konsep materi pelajaran, penyajian materi, bahasa, dan kegrafikaan dapat dipertanggungjawabkan. Para ahli memberi skor rata-rata 3.59 (skor 3 = layak; skor $4=$ sangat layak). Hal ini berarti menurut ahli, model buku ajar yang dikembangkan sudah tergolong layak. Hal ini merupakan salah satu persyaratan untuk suatu buku ajar yang harus dipenuhi sehingga dapat dipergunakan untuk keperluan pembelajaran di kelas.

Hasil penilaian yang diberikan oleh praktisi, yakni guru, menunjukkan bahwa model buku ajar yang dikembangkan dipandang dari segi kelayakan materi pelajaran, penyajian materi, bahasa, dan kegrafikaan dapat dipertanggungjawabkan. Para guru memberi skor ratarata 3.82 (skor 3 = layak; skor $4=$ sangat layak). Hal ini berarti menurut para guru, model buku ajar yang dikembangkan sudah tergolong sangat layak sehingga dapat dipergunakan untuk keperluan pembelajaran membaca di kelas.

Hasil penilaian yang diberikan oleh pengguna, yakni peserta didik, menunjukkan bahwa model buku ajar yang dikembangkan dipandang dari segi kemudahan penggunaan dapat dipertanggungjawabkan. Para peserta didik memberi skor rata-rata 3.85 (skor $3=$ layak; skor $4=$ sangat layak). Hal ini berarti menurut para peserta didik, model buku ajar yang dikembangkan sudah tergolong sangat layak sehingga dapat dipergunakan untuk keperluan pembelajaran membaca di kelas.

Berdasarkan data yang diperoleh terdapat kritik, saran, atau komentar dalam uji produk baik dari ahli, guru, maupun peserta didik. Berdasarkan kritik, saran, dan komentar tersebut telah dilakukan perbaikan terhadap model buku ajar yang dikembangkan. Perbaikan yang dilakukan mencakup (1) ketepatan penggunaan kata dan istilah; (2) ketepatan penggunaan ejaan; dan (3) tata letak dan gambar.

Seperti sudah diungkapkan sebelumnya, buku ajar membaca yang dikembangkan di- dasarkan atas pendekatan tertentu dalam pembelajaran membaca, yakni pendekatan proses. Pendekatan ini dikembangkan oleh Tomkins \& Hoskisson (1995) dan Tomkins (2010). Dengan demikian, buku ajar Membaca Berdasarkan Pendekatan Proses bagi Siswa SMP yang dikembangkan dalam penelitian ini sudah memenuhi syarat metodologis dalam penyusunan bahan ajar sebagaimana dinyatakan oleh Sumardi (2000).

Isi pembelajaran membaca yang dikembangkan dalam model buku ajar mencakup paparan teori, contoh teks, materi latihan, dan materi penugasan. Hal ini sesuai dengan pendapat Tomkins \& Hoskisson (1995: 42), bahwa dalam pembelajaran bahasa, buku pelajaran merupakan suatu sarana untuk pembelajaran prosedur, konsep, strategi, dan praktik berbahasa.

Model buku ajar yang dikembangkan ini juga memuat berbagai contoh teks yang dikaji peserta didik. Contoh teks ini disajikan sebagai bahan kegiatan membaca peserta didik. Oleh karena itu, contoh teks yang dipilih adalah teks yang otentik. Hal ini sesuai dengan pandangan Crawford (2002:44-47), bahwa dalam menyusun buku ajar pembelajaran bahasa harus diperhatikan keotentikan contoh teks yang disajikan.

Kegiatan penugasan, berupa perintah agar peserta didik melakukan suatu kegiatan dalam rangka mendapatkan pengalaman untuk melakukan kegiatan berbahasa, juga disajikan dalam buku ajar yang dikembangkan. Penugasan merupakan aspek penting dalam pengembangan materi pembelajaran bahasa. Hal ini sesuai dengan pandangan Tomkins \& Hoskisson (1995: 42), bahwa dalam buku pelajaran disajikan konsep, contoh, dan kegiatan latihan berbahasa. Menurut Ur (2009), penugasan itu hendaknya disampaikan dengan jelas agar dapat dipahami sendiri oleh peserta didik.

Aspek penyajian materi pembelajaran yang tertuang dalam buku ajar yang dikembangkan mencakup adanya kejelasan tujuan pembelajaran, penahapan pembelajaran, kemudahan bahan untuk dipahami, dan keaktifan peserta didik. Tujuan pembelajaran merupakan target pencapaian kompetensi dasar yang harus dikuasai oleh peserta didik. Oleh karena itu, 
dalam tujuan pembelajaran ini dideskripsikan kompetensi dasar dan indikator yang terdapat pada setiap awal unit kegiatan pembelajaran seperti contoh berikut ini.

Penahapan pembelajaran merupakan urutan kegiatan pembelajaran yang diikuti oleh peserta didik ketika menggunakan materi sebagai sumber ajar. Oleh karena itu, penahapan materi yang dikembangkan dalam model buku ajar membaca berdasarkan pendekatan proses mencakup pramembaca, membaca, merespon, menggali teks, dan memperluas pemahaman. Tahapan penyajian materi pembelajaran ini sesuai dengan pendapat Tomkins \& Hoskisson (1995) dan Tomkins (2010).

Materi pembelajaran menulis yang dikembangkan juga mengandung aspek keaktifan peserta didik. Hal ini ditandai oleh penyajian petunjuk dan perintah yang harus dilakukan oleh peserta didik baik secara individu maupun kelompok. Petunjuk ini disusun dengan bahasa yang komunikatif agar mudah dipahami oleh peserta didik. Hal ini sesuai dengan saran Ur (2009:193), antara lain, agar instruksi dalam materi pembelajaran ditulis dengan singkat dan jelas. Keaktifan peserta didik tampak ketika ia mengikuti lima tahapan kegiatan yang harus diikuti ketika menggunakan buku ajar membaca berdasarkan pendekatan proses yang dikembangkan dalam penelitian ini, yakni (1) pramembaca, (2) membaca, (3) merespon, (4) menggali teks, dan (5) memperluas pemahaman.

Dalam pengembangan model buku ajar membaca ini, bahasa digunakan untuk menjelaskan petunjuk, memaparkan teori, dan menyatakan tugas atau latihan. Oleh karena itu, dalam pengembangan materi buku ajar ini digunakan kalimat yang singkat dan jelas sehingga mudah dipahami oleh peserta didik.

Aspek kegrafikaan model buku ajar yang dikembangkan mencakup (1) ukuran buku, (2) tata letak, tipografi, dan ilustrasi sampul, dan (3) tata letak, tipografi, dan ilustrasi isi. Ukuran buku meliputi tinggi $29 \mathrm{~cm}$ dan lebar 20,5 cm atau A4. Ukuran ini sesuai dengan standar ISO dan standar fisik penulisan buku pelajaran (Gardjito, 2005; Depdiknas, 2006a; Depdiknas, 2006b).
Tata letak sampul menunjukkan bahwa tulisan yang tercantum dalam sampul materi pembelajaran menulis itu mencakup (1) judul buku ajar Buku Ajar Membaca Berdasarkan Pendekatan Proses bagi Siswa SMP dicetak tegak dengan huruf kapital di tengah; (2) nama penulis dicetak di tengah; (3) nama lembaga tercetak Universitas Negeri Yogyakarta Fakultas Bahasa dan Seni, Program Studi Pendidikan Bahasa Indonesia dan (4) tahun penyusunan 2012 dicetak tegak di bagian tengah bawah.

Tata letak isi menunjukkan penempatan tata letak yang konsisten antara unit pelajaran yang satu dengan yang lain. Setiap unit materi pelajaran dijabarkan dengan pola: (1) judul unit pembelajaran, (2) kompetensi dasar, (3) pramembaca, (4)membaca, (5) merespon, (6) menggali teks, dan (7) memperluas pemahaman. Selain itu, penempatan bab, subbab, dan nomor halaman juga dilakukan secara konsisten. Penempatan bidang cetak, marjin, dan spasi juga dilakukan secara konsisten. Pengaturan tata letak isi materi pembelajaran menulis tersebut sesuai dengan standar fisik penulisan buku pelajaran (Gardjito, 2005).

Tipografi isi penulisan materi pembelajaran menunjukkan penggunaan huruf yang tidak terlalu banyak, yakni hanya dua jenis huruf (huruf Palatino Linotyp dan Arial). Selain itu, juga tidak digunakan jenis huruf hias dan jenis huruf yang berlebihan. Penggunaan tipografi isi materi pembelajaran ini sesuai dengan standar fisik penulisan buku pelajaran (Gardjito, 2005).

Ilustrasi isi materi pembelajaran menunjukkan penggunaan gambar atau foto otentik yang disesuaikan dengan isi materi. Penggunaan ilustrasi yang berupa gambar atau foto otentik itu dimaksudkan agar menimbulkan daya tarik dan memudahkan peserta didik untuk memahami isi materi pembelajaran. Penggunaan ilustrasi isi materi pembelajaran ini sesuai dengan standar fisik penulisan buku pelajaran (Gardjito, 2005).

\section{PENUTUP}

Pada tahap pertama (tahun 2012) penelitian pengembangan ini telah berhasil mengembangkan model Buku Ajar Membaca Berdasar- 
kan Pendekatan Proses bagi Siswa SMP. Buku ajar yang dimaksud terdiri dari tiga bagian, yakni (1) bagian pendahuluan, (2) bagian isi, dan (3) bagian tambahan. Bagian pendahuluan terdiri dari sampul, kata pengantar, dan daftar isi. Bagian isi terdiri dari sepuluh unit pelajaran membaca, yakni (1) membaca memindai, (2) membaca cepat, (3) membaca cerita anak, (4) membaca dan mengomentari buku cerita, (5) membaca indah puisi, (6) membaca cerita anak dan menemukan realitas dalam kehidupan, (7) membaca intensif buku biografi, (8) membaca intensif untuk menemukan gagasan utama, (9) membaca tabel/diagram, dan (10) membaca teks perangkat upacara. Setiap unit pelajaran membaca itu, dikembangkan dengan pola urutan judul unit pembelajaran, kompetensi dasar, pramembaca, membaca, merespon, menggali teks, dan memperluas pemahaman. Sementara itu, bagian tambahan model buku ajar yang dikembangkan berupa daftar pustaka. Hasil uji ahli, uji praktisi (guru), dan uji pengguna (peserta didik) menunjukkan bahwa model buku ajar yang dikembangkan termasuk ke dalam kategori layak atau baik.

Sesuai dengan hasil penelitian tersebut, disarankan agar dilakukan kegiatan penelitian tahun kedua yang ditujukan untuk mengetahui keefektifan model Buku Ajar Membaca Berdasarkan Pendekatan Proses bagi Siswa SMP yang telah dikembangkan. Jenis penelitian yang tepat untuk membuktikan kefeektifan produk itu adalah penelitian eksperimen.

\section{UCAPAN TERIMA KASIH}

Penelitin ini dilaksanakan dengan sumber dana penelitian unggulan dengan surat perjanjian Pelaksanaan Penelitian Unggulan Universitas Negeri Yogyakarta Nomor: 012/Subkontrak-Unggulan/UN34.21/2012. Oleh karena itu, peneliti mengucapkan terima kasih kepada Rektor dan Ketua Lembaga Penelitian dan Pengabdian pada Masyarakat Universitas Negeri Yogyakarta yang telah membantu pelaksanaan penelitian ini.

\section{DAFTAR PUSTAKA}

Crawford, J. 2002. "The Role A Material in Language Classroom." Dalam Richard, J.C, \& Renandya, W.A. (Eds.). Methodology in Language Teaching: An Anthology of Current Practice (Hlm. 84-87. Cambridge: Cambridge University Press.

Depdiknas, 2006a. Pedoman Penulisan Buku Pelajaran, Penjelasan Standar Mutu Buku Pelajaran Bahasa Indonesia. Jakarta: Pusat Perbukuan, Departemen Pendidikan Nasional.

Depdiknas. 2006b. Pemilihan dan Pemanfaatan Buku Teks Pelajaran yang Memenuhi Syarat Kelayakan. Jakarta: Pusat Perbukuan, Departemen Pendidikan Nasional.

Gardjito. 2005. Pedoman Standarisasi Fisik Buku Pelajaran. Jakarta: Pusat Perbukuan, Departemen Pendidikan Nasional.

Hyland, K. 2007. Second Language Writing. 4th Printing. Cambridge: Cambridge Univseristy Press.

Mullis, I.V.S., Martin, M.O., Foy, P., \& Drucker, K.T. 2012. PIRLS 2011 International Result ini Reading. Chelstnut Hill, MA: Boston College.

Muslich, M. 2010. Text Book Writing, Dasardasar Pemahaman, Penulisan, dan Pemakaian Buku Teks. Yogyakarta: ArRuzz Media.

Sumardi. 2000. Buku Pelajaran Bahasa Indonesia SD sebagai Sarana Pengembangan Kepribadian, Penalaran, Kreativitas, dan Keterampilan Berkomunikasi Anak. Jakarta: Grasindo.

Tomkins, G.E. \& Hoskisson, K. 1995. Language Arts: Content and Teaching Strategies. Englewood Cliffs, New Jersey: Merrill. 
Tomkins, G.E. 2010. Literacy for the $21^{\text {st }}$ Century, A Balanced Approach. Boston: Allyn Bacon.

Tomlinson, B. 1998. Material Development in Language Teaching. Cambridge: Cambridge University Press.
Ur, P. 2009. A Course in Language Teaching: Practice and Theory. 17 Printing. Cambridge: Cambridge University Press.

Willis, J. 1995. "A Recursive, Reflective Instructional Design Model Based on Constructivist-Interpretative Theory." Educational Technology, 1995, 35, (6), pp 5-23. 